\title{
Trend Analysis of the Demand and Supply of University Admission Places in Delta State University (2013 - 2017)
}

\author{
Vinella Okonta \\ Department of Educational Management \& Foundations, Delta State University, Abraka, Nigeria
}

Received October 9, 2020; Revised November 25, 2020; Accepted December 13, 2020

\begin{abstract}
Cite This Paper in the following Citation Styles
(a): [1] Vinella Okonta, "Trend Analysis of the Demand and Supply of University Admission Places in Delta State University (2013 - 2017)," Universal Journal of Educational Research, Vol. 8, No. 12B, pp. 8118-8128 2020. DOI: 10.13189/ujer.2020.082614.
\end{abstract}

(b): Vinella Okonta (2020). Trend Analysis of the Demand and Supply of University Admission Places in Delta State University (2013 - 2017). Universal Journal of Educational Research, 8(12B), 8118-8128. DOI: 10.13189/ujer.2020.082614.

Copyright $\mathrm{C} 2020$ by authors, all rights reserved. Authors agree that this article remains permanently open access under the terms of the Creative Commons Attribution License 4.0 International License

\begin{abstract}
This study traced the trend of demand and supply of university admission places in Delta State University for 2013/14 to 2017/18 academic sessions vis-à-vis the prevailing situation in Nigeria. It adopted the ex post facto design. Three research questions were raised to guide the study. Findings revealed a worrisome gap between the total numbers of applicants and admitted candidates per session and pointed out that 102,594 was the total number of applicants while 29,460 representing $28.72 \%$ was the total number of admitted candidates for the five (5) years under review. It equally shows Clinical Medicine and Pharmacy as faculties with the least numbers of admissions. The study recommended that stakeholders should think of ways and means of expanding the university's 'carrying capacity' as well as attract adequate qualified manpower to enable the institution absorb more applicants. Again, it is recommended amongst other things that programmes such as Sandwich, Part-time programme and Continuous Education Programme (CEP) should be re-introduced as strategies of giving more applicants the opportunities to be admitted.
\end{abstract}

Keywords Analysis, Demand, Supply, University Admission, Applicants, Admitted Candidates

\section{Introduction}

Higher education in general and university education in particular has been a breeding ground for persons with intellectual capacities to be trained for middle and high level manpower requirement of nations. The higher education system consists of the university and the non-university sector - polytechnics, monotechnics and colleges of education. The National Policy on Education [1] spelt out the goals of higher education to include:

a). Contribute to national development through high level relevant manpower training;

b). Develop and inculcate proper values for the survival of the individual and society;

c). Develop the intellectual capability of individuals to understand and appreciate their local and external environments;

d). Acquire both physical and intellectual skills which will enable individuals to be self-reliant and useful members of the society; amongst others.

Higher education in Nigeria and by extension university education the world over has been perceived as the only means to a good life; as individuals are becoming more and more aware of the environment in which they live and the ways and means of survival. It is an indispensable tool for promoting the socio-economic, political and cultural development of nations as it produces and provides the high level manpower requirement of nations. It is in recognition of this fact that secondary school leavers and other members of the society not too educated crave for university education at an overwhelming rate beyond what the government can provide.

It is an established fact that Nigerian population has been growing rapidly over the years. By year 2019, the country's population was estimated at 200,963,599 at an annual growth rate of $2.60 \%$ [2]. The World Education News and Reviews, Western Education Service [3] reported that over $60 \%$ of Nigerian population is under the age of 24. This shows the rapid growth in the youth population, that is, the school age population. To be able 
to provide adequate higher education for this teaming youth population, the government has increased the number of universities in Nigeria to 174 [4]; polytechnics 132 (https://www.myschoolgist.com), monotechnics 26 (https://www.samphina.com.ng); and colleges of education 152 (https://en.m.wikipedia.org) in various fields of studies. But these notwithstanding, admission into Nigerian universities has become very competitive as the increased demand for university education has over the years remained unabated despite the expansion efforts of the federal and state governments including private universities.

\section{Purpose of Study}

The study investigated the number of applicants and admitted candidates in Delta State University for the period 2013/14 - 2017/18 academic years. In specific terms, the study was carried out to:

1. examine the total numbers of applicants and admitted candidates across all disciplines in DELSU for the academic years under review;

2. ascertain the total numbers of applicants and admitted candidates per faculty per year in DELSU for the academic years under review;

3. analyze and determine the percentage rate of admissions per faculty per session for the period under review.

Therefore, this study seeks to:

1) Define the concepts 'demand' and 'supply' as they relate to university education;

2) Give an overview of demand for and supply of university admission places as well as its attendant challenges with particular reference to Nigeria;

3) Trace the trend of demand for and supply of university admission places in Delta State University from 2013/2014 to 2017/2018 academic years;

4) Point out the study's implications for educational planning;

5) Recommend ways of curbing the identified challenges.

\section{The Concepts "Demand" and "Supply" in Relation to Education}

The word 'demand' is an economic concept used to express the desire of a person, group of persons or a society to purchase good and/or services at a particular price within a given period of time. William [5] defined demand as "the quantity of a product or service that consumers are both willing and able to buy at each possible price, during a given period of time, other things held constant'. In other words, the law of demand states that the quantity demanded of a particular good or service at a particular time is dependent on the price at which the good or service is being sold or rendered respectively at that time. That is, the lower the price of a good or service, the higher the quantity to be demanded and the higher the price, the lower the quantity to be demanded. To establish demand, this desire must be backed by the ability to acquire as well as the willingness and capability to pay for such goods and/or services.

In relation to education, Nwadiani [6] saw demand as 'the amount of a commodity like education that would be bought at a price over a period of time. On his part, Agabi [7] defined demand for education as the total number of persons who have expressed the desire to acquire a given type or level of education at a point in time and who possess not only the capacity to acquire it but also the willingness and the capability to pay for it'.

The above definitions point out in clear terms the conditions that must be satisfied before we can establish the actual demand for education. Agabi [7] enumerated these to include:

1) That there must be expressed desires to acquire education in the form of application forms or requests from candidates for admission places.

2) That candidates must satisfy the basic entry qualifications required for each type or level of education desired.

3) That the person or persons desiring to acquire any type or level of education must have the willingness to pay all the costs that must be incurred to acquire that education.

4) That the person or persons must have the capability to pay all the costs, suffer all the inconveniences necessary to acquire the type or level of education so desired.

It is only when these conditions are met that we can truly establish that there is an effective demand for any type or level of education. Again, the peculiar nature of education as a social good, public good, consumption good and an economic good has made it impossible for candidates to demand less education despite its rising cost.

The concept 'supply' on the other hand is an economic concept that describes the total amount of a specific good or service that is available to consumers at a specific price or the amount available across a range of prices if displayed on a graph. It is defined as the willingness and ability of producers to create goods and services to take them to market. The law of supply indicates how much of a good or service a producer is willing and able to offer for sale at each possible price, other things held constant [5]. It states that the quantity supplied is usually directly related to its price, therefore, the lower the price, the lower the quantity to be supplied.

Relating this to the supply of education, Nwadiani [6] pointed out that the supply of education is heavily dependent on government resources, endowment and the political 'will' to support education. The author opined that only few countries anywhere in the world are in a position to provide as much education as may be demanded and decision makers must seek to reconcile private demand and public need.

From the foregoing, supply of university education can therefore be defined as the quantity/number of university admission places that the federal and state governments through their agency - Joint Admission and Matriculation 
Board (JAMB), the public universities and the private universities are willing and able to offer to the teaming applicants at a possible price, all things being equal.

Just like the demand for education, certain factors affect the supply of university education. They include but are not restricted to:

1) The federal government policy of 60:40 admission ratio for science and humanity based courses;

2) The government policy on deregulation of university education;

3) Insufficient number of universities;

4) The challenge of 'carrying capacity' of the nation's universities;

5) Inadequate educational facilities and infrastructures;

6) Quota system and catchment policy of the federal government;

7) The challenge of inadequate funding.

These are to be discussed briefly in the next segment of this paper.

\section{An Overview of the Trend of Demand for and Supply of University Education in Nigeria}

Generally, education is an indispensable tool for promoting socio-economic, political and cultural development of nations. University education in particular is essentially important and useful to man and his society as it is fundamental to the construction of a knowledge-based economy and society in all nations. The ever increasing importance of university education as a means of strengthening the economy and availing the individual the opportunity to acquire both physical and intellectual skills which will enable him to be self-reliant and useful member of the society [1] has intensified the demand for university education amongst the teaming population of Nigerian youths.

With a total population of about 201 million [2,3] reported that Nigeria's higher education sector has been overburdened by strong population growth and a significant 'youth bulge' as more than 60 percent of the country's population is under the age of 24 . In absolute terms, supplying education at all levels - primary, secondary and tertiary to above 60 percent of the total population has become a difficult task for the federal and state governments in the midst of other competing/contending needs of the nation. As pointed out by Ajayi and Ekundayo [8], 'Nigeria higher education has not been able to meet the demand for broadening college admissions'. The government has not been able to meet the huge demand of education despite the proliferation of private universities [9].

Clark and Ausukuya [10] reported that in recent years, there has been steady growth in the number of universities approved to award degrees as the government attempts to respond to rapidly increasing demand; despite the fact that there is currently still more demand than there is supply of places. In the same vein, Abubakar Rasheed, the NUC Executive Secretary cited by Adedigba [9] stated that only $1 \%$ of Nigerian population are in universities and described the situation as 'unhealthy'. According to the author, with a population of about 200 million and a total enrolment of 1.961 million (less than 2 million) in all the nation's universities, this translates to roughly $1 \%$ of the population.

With only University of Ibadan, an affiliate of the University of London in 1948, six universities at the early years of independence between 1960 - 1972 [11], Nigeria now has 174 universities made up of 43 federal, 52 states and 75 private universities [4]. But the number of these universities notwithstanding, securing admissions into the nation's universities especially the public ones has continued to be a mirage. A look at the trend of the demand for and supply of admission places in Nigerian universities shows that the number of applicants (demand) far outweighs the available admission places.

Table 1. Demand and Supply of University Education in Nigeria (2010 2018)

\begin{tabular}{|c|c|c|c|c|}
\hline Year & $\begin{array}{c}\text { No. of } \\
\text { Applicants } \\
\text { (Demand) }\end{array}$ & $\begin{array}{c}\text { No. } \\
\text { Admitted } \\
\text { (Supply) }\end{array}$ & $\begin{array}{c}\% \\
\text { Admitted }\end{array}$ & $\begin{array}{c}\text { \% Not } \\
\text { Admitted }\end{array}$ \\
\hline 2012 & $1,503,933$ & 410,157 & 27.27 & 72.73 \\
\hline 2013 & $1,668,314$ & 400,157 & 23.99 & 76.01 \\
\hline 2014 & $1,632,172$ & 379,793 & 23.26 & 76.74 \\
\hline 2015 & $1,428,379$ & 415,500 & 29.08 & 70.92 \\
\hline $2016^{*}$ & $1,557,017$ & 405,467 & 26.04 & 73.96 \\
\hline $2017 *$ & $1,687,551$ & 418,391 & 24.79 & 75.21 \\
\hline $2018 *$ & $1,793,018$ & 442,353 & 24.67 & 75.33 \\
\hline Total & $\mathbf{1 1 , 2 7 0 , 3 8 4}$ & $\mathbf{2 , 8 7 1 , 8 1 8}$ & $\mathbf{2 5 . 4 8}$ & $\mathbf{7 4 . 5 2}$ \\
\hline
\end{tabular}

Source: $[12,13,14,15]$

This is graphically presented thus: Figure 1: 


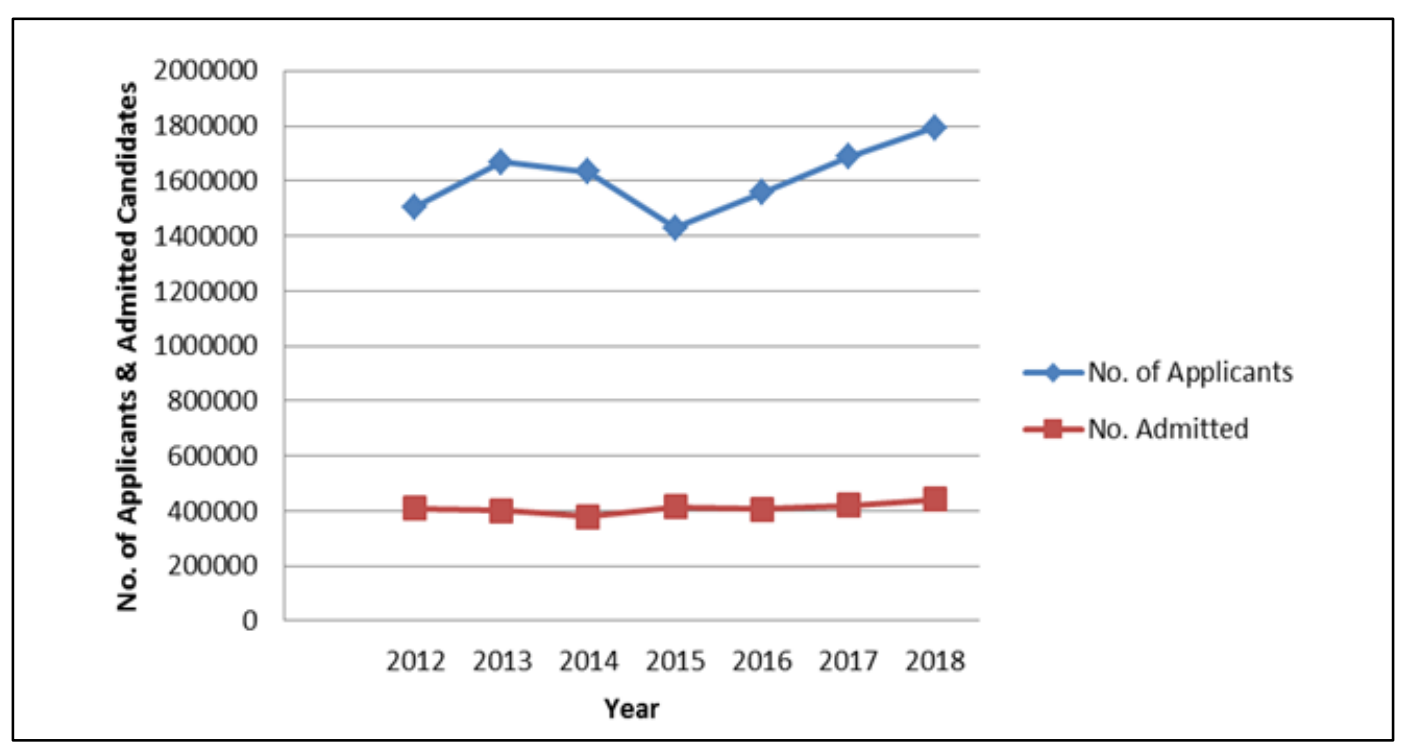

Figure 1. Demand \& Supply of University Admission Places in Nigeria 2012 - 2018

A number of factors (challenges) could be responsible for the 'unhealthy' and ugly trend in the admission of candidates into the nation's universities. They include:

1) Federal Government 60:40 Admission Ratio Policy: One of the challenges affecting the number of candidates admitted into Nigerian universities yearly is the issue of the federal government policy of 60:40 admission ratio for the science and humanity based disciplines respectively. This policy emanated from the fact that the nation needed more scientists in all sectors of the economy for the much needed technological development. The implication of this policy is that many of the humanity based qualified candidates would be denied admission in view of the fact that the slots allotted for them are not enough to admit majority of the candidates. For instance, Otoja and Obodumu [16] reported that between 2012 and 2015, disciplines such as Engineering/Environmental Technology, Medicine and Sciences have higher admission for each year; and that for 2015, the cumulative admission for sciences and arts related disciplines are 2,013,123 and 157,336 respectively.

2) Insufficient Number of Universities: Another worrisome challenge to the ugly trend in the demand and supply of university admission places in Nigeria has been the issue of insufficient number of universities. With a rapid growth rate in the nation's population which was estimated at about $3.2 \%$ (Population Institute Canada, cited by Parr, 2018), the school age population had equally 'bulged' over the years. It was reported that above $60 \%$ of the total population are under age $24[3,16]$. The implication of this is that the 99 public universities currently available are not just enough to accommodate the high demand for university education. Again, the 75 private universities (which are out of the reach of the generality of the applicants because of their exorbitant charges) account for only $5.31 \%$ of the total enrollment in universities across the country [9].
Furthermore, he stated that there is need for more access either by creating more universities or expanding existing ones. But the question now as posed by Adedigba [9] is: "How do you start building new universities when there is not a single one amongst the existing universities that is up to the standard of a university in the real sense of it?" This is a question that only time will answer.

3) Government Policy on Deregulation of University Education: Deregulation of university education means breaking government's monopoly of the provision of university education by allowing private participation in management of university education in the country. By this act, the government has dismantled the legal and governmental restrictions on the operations of education business [17]. It has withdrawn its controls in the allocation of resources and in the production process of the graduates of these licensed private universities. Deregulation was borne out of the fact that these licensed private universities were to complement government's efforts at providing education to the masses; especially in the area of increasing access to university education in order to address the problem of excessive demand over supply as well as the problem of scarce educational resources as many of the public universities lack adequate and modern educational facilities required for the present day educational service delivery. This act of the government has a lot of implications for easy access to university education: 1) Some private universities lower standards for attraction of applicants [17]; 2) They charge fees, which candidates from poor families cannot afford to pay [18]; and 3) They maximize profits from their investments in education [17] in order to keep up their financial demands to be able to remain in business. In absolute terms, deregulation has not actually improved access to university education as the 75 private universities currently available accounts for 
$5.31 \%$ of the total enrollment in the universities across the country [9].

4) The Challenge of 'Carrying Capacity': The issue of carrying capacity has greatly reduced the number of admissions into Nigerian universities. This policy of the National Universities Commission (NUC) stipulates the number of candidates to be admitted by each university. This they do based on the available human and physical facilities/infrastructures of these universities. Parr [16] on his part, opined that many conventional universities in good standing with respect to quality are being encouraged by NUC to switch to a dual mode, with a strong open and distance learning delivery system. This according to him, would 'significantly bolster' the carrying capacities of these existing universities. The implications of these assertions can be seen in Table 1, Figure 1 which showed that of the 11,270,384 applicants for admission between 2012 - 2018, only $2,871,818$ representing $25.48 \%$ was offered admission for a period of seven years $[12,13,14,15]$.

5) Inadequate Funding: The nation's educational sector especially the university system has over the years experienced gross underfunding. Akpotu [19] observed that education in Nigeria has been grossly underfunded and that it is worrisome to note that over $90 \%$ of the federal and state government's annual appropriations for education are used for the payment of salaries and allowances with virtually nothing allocated to research and less than $10 \%$ for capital projects and procurement of teaching materials. The growth in the population has resulted in the ever increasing demand for university education. While the federal and state government's efforts at increasing capacity by building new universities have generally been positive for access in absolute terms, they have also created issues related to instructional quality [3]. This is because expansion of the university system in Nigeria has not been directly associated with enhanced funding for these universities to thrive. Citing Aluede et al [20], Mahabub [21] stated that in the year 1999, the budget of $11.2 \%$ allocated for education reduced to $5.9 \%$ in 2002 and $1.83 \%$ in 2003 . By 2015, 12.28\% of the total national budget was allocated to education. This has substantially reduced to $6.48 \%$ in the 2020 budget [22]. The above figures fall short of the $26 \%$ minimum standard stipulated by UNESCO and NEEDS Assessment Report (2012). The implication of this is that the funding pattern is not commensurate with the growth in number of universities; as such, the universities will continue to lack the basic infrastructures and facilities necessary to improve enrollment.

6) Inadequate Educational Facilities/Infrastructures: Adequacies of educational facilities and infrastructures are very crucial components in the delivery of university education. Akpotu [23] noted that the basic facilities for quality education are seriously lacking due to under-investment. The author posits that the poor state of infrastructures frequently causing students to study subjects mainly in the humanities and arts, which offer limited job opportunities creating a large pool of "educated unemployed" as well as a pool of unmet demand for qualified science and technology graduates. Again, Otoja and Obodumu [18] opined that inadequate provision of human and material resources especially instructional facilities due to poor funding resulted in the formation of the 'principles of faculty carrying capacity' which stipulates that admission of students should be based on available facilities - staff, classrooms, laboratories, libraries, equipment and materials. Availability and adequacy of these essential facilities are the factors considered by the NUC in determining the carrying capacity of each university. Therefore, this challenge is the resultant effect of inadequate funding; and its implications on education especially university education are the reduced admission quotas and quality of teaching and learning.

7) Quota System Policy of the Government: In an attempt to create equal opportunities for admission seekers from the various ethnic groups in the country, the federal government introduced the quota system policy as "an indispensable tool for inter-ethnic unity, harmony and social cohesion of the whole country [24]". This policy of the federal government and the NUC entails that preferences are given to the indigenous places where the universities are located in considering candidates for admission. Again, all the states of the federation are grouped into catchment areas of each federal university in order to give all applicants equal opportunities. Okoroma [25], Otoja and Obodumu [18] explained that the quota system policy consists of such elements as: 1) academic merit determined by the candidate's UME scores and this is allotted $45 \%$ of available spaces; 2) catchment area which ensures that $25 \%$ of available spaces must be reserved for indigenes of the area where the university is situated; 3) backwardness policy which ensures that $20 \%$ of available spaces must be reserved for indigenes of states considered to be educationally 'disadvantaged' or 'backward'; and 4) vice-chancellor's discretion which ensures that $10 \%$ of available spaces must be reserved for the discretion of the vice-chancellor. Application of these policies in the admission procedures into the nation's universities have deprived many bright, intelligent and even exceptional applicants the opportunity of accessing university education. Babalola [26], Eluemunor [27] and Mahabub [21] believe that many unqualified candidates have been offered admissions into Nigeria universities through JAMB as a result of these policies. This can be very frustrating. The implication of this is that the quality of university education has consequently been lowered as a result 
of these policies which apparently de-emphasize quality in the selection process [28].

Demand and Supply of University Admission Places in Delta State University, Abraka (2013/2014 - 2017/2018)

A trend analysis of the demand for and supply of university admission places in Nigeria revealed that the gap between demand (applications) and supply (admissions) is widening over the years as noted by Akpotu [23]. To this end, it has become necessary to examine the situation in Delta State University, Abraka.

\section{Research Questions}

To guide this study, three research questions were posed. These are:

1. What were the total numbers of applicants and admitted candidates across all disciplines in Delta
State University for the 2013/14 - 2017/18 academic years?

2. What were the total numbers of applicants and admitted candidates per faculty per academic year in DELSU for the period under review?

3. What was the percentage rate of admissions offered per academic year for the period 2013/14 - 2017/18?

\section{Methods}

The study adopted the ex post facto design as it described the applicants and admissions' situation in DELSU as at the academic years under review. A self-developed checklist titled, 'Demand and Supply of University Admission Places Checklist' was used to elicit data from the Admissions Unit of the University. The data so obtained were analysed using descriptive statistics tables, percentages and graphs. 


\section{Data Presentation and Analysis}

Table 2. Demand and Supply of Admission Places in Delta State University by Faculty 2013/2014 - 2017/2018 Academic Years

\begin{tabular}{|c|c|c|c|c|c|c|c|c|c|c|c|c|}
\hline \multirow{3}{*}{ Faculty } & \multicolumn{12}{|c|}{ Applicants, No. Admitted, \% Admitted and \% Not Admitted Per Year Per Faculty } \\
\hline & \multicolumn{4}{|c|}{$2013 / 2014$} & \multicolumn{4}{|c|}{$2014 / 2015$} & \multicolumn{4}{|c|}{$2015 / 2016$} \\
\hline & $\begin{array}{l}\text { No. of } \\
\text { Appli. }\end{array}$ & $\begin{array}{c}\text { No. } \\
\text { Admitted }\end{array}$ & $\%$ Admitted & $\begin{array}{c}\% \text { Not } \\
\text { Admitted }\end{array}$ & $\begin{array}{c}\text { No. of } \\
\text { Appli }\end{array}$ & $\begin{array}{c}\text { No. } \\
\text { Admitted }\end{array}$ & $\%$ Admitted & $\begin{array}{c}\% \text { Not } \\
\text { Admitted }\end{array}$ & $\begin{array}{l}\text { No. of } \\
\text { Appli. }\end{array}$ & $\begin{array}{c}\text { No. } \\
\text { Admitted }\end{array}$ & $\%$ Admitted & $\begin{array}{c}\% \text { Not } \\
\text { Admitted }\end{array}$ \\
\hline Agriculture & 99 & 280 & 282.82 & 0 & 104 & 206 & 198.07 & 0 & 142 & 389 & 273.94 & 0 \\
\hline Arts & 886 & 797 & 92.03 & 7.97 & 659 & 700 & 106.22 & 0 & 1107 & 745 & 67.29 & 32.71 \\
\hline Basic Med. Sci. & 1932 & 699 & 36.18 & 63.82 & 1703 & 524 & 30.76 & 69.24 & 2982 & 797 & 26.72 & 73.28 \\
\hline Clinical Medicine & 1432 & 58 & 4.05 & 95.95 & 1803 & 78 & 4.32 & 95.68 & 2874 & 65 & 2.26 & 97.74 \\
\hline Education & 2582 & 2038 & 78.93 & 21.07 & 2085 & 1111 & 53.28 & 46.72 & 2873 & 1638 & 57.01 & 42.99 \\
\hline Engineering & 2477 & 0 & 0 & 100 & 0 & 0 & 0 & 100 & 0 & 0 & 0 & 100 \\
\hline Law & 1542 & 175 & 11.34 & 88.66 & 1692 & 155 & 9.16 & 90.84 & 2676 & 145 & 5.41 & 94.59 \\
\hline Mgt Sciences & 3083 & 265 & 8.59 & 91.41 & 2025 & 319 & 15.75 & 84.25 & 4611 & 430 & 9.32 & 90.68 \\
\hline Pharmacy & 624 & 71 & 11.37 & 88.63 & 643 & 84 & 13.06 & 86.94 & 1191 & 94 & 7.89 & 92.11 \\
\hline Science & 2947 & 1711 & 58.05 & 41.95 & 1419 & 928 & 65.39 & 34.61 & 2313 & 1486 & 64.24 & 35.76 \\
\hline Social Science & 3001 & 640 & 21.32 & 78.68 & 3811 & 597 & 15.66 & 84.34 & 5843 & 691 & 11.82 & 88.18 \\
\hline Total & 20605 & 6734 & 32.68 & 67.32 & 15944 & 4702 & 29.49 & 70.51 & 26612 & 6480 & 24.34 & 75.66 \\
\hline
\end{tabular}

\begin{tabular}{|c|c|c|c|c|c|c|c|c|}
\hline \multirow{3}{*}{ Faculty } & \multicolumn{8}{|c|}{ Applicants, No. Admitted, \% Admitted and \% Not Admitted Per Year Per Faculty } \\
\hline & \multicolumn{4}{|c|}{$2016 / 2017$} & \multicolumn{4}{|c|}{$2017 / 2018$} \\
\hline & No. of Appli. & No. Admitted & $\%$ Admitted & $\%$ Not Admitted & No. of Appli. & No. Admitted & $\%$ Admitted & $\%$ Not Admitted \\
\hline Agriculture & 182 & 219 & 120.32 & 0 & 96 & 169 & 176.04 & 0 \\
\hline Arts & 1276 & 708 & 55.48 & 44.52 & 971 & 557 & 57.36 & 42.64 \\
\hline Basic Med. Sci. & 3826 & 732 & 19.13 & 80.87 & 2044 & 793 & 38.79 & 61.21 \\
\hline Clinical Medicine & 3269 & 66 & 2.01 & 97.99 & 1346 & 77 & 5.72 & 94.28 \\
\hline Education & 2816 & 1519 & 53.94 & 46.06 & 1145 & 1089 & 95.1 & 4.9 \\
\hline Engineering & 0 & 45 & & 100 & 665 & 230 & 34.58 & 65.42 \\
\hline Law & 1115 & 0 & 0 & 100 & 461 & 129 & 27.98 & 72.02 \\
\hline Mgt Sciences & 3515 & 353 & 10.04 & 89.96 & 870 & 326 & 37.47 & 62.53 \\
\hline Pharmacy & 1593 & 95 & 5.96 & 94.04 & 974 & 106 & 10.88 & 89.12 \\
\hline Science & 2479 & 1495 & 60.34 & 39.66 & 1901 & 1409 & 74.11 & 25.89 \\
\hline Social Science & 4941 & 758 & 15.34 & 84.66 & 3948 & 669 & 16.94 & 83.06 \\
\hline Total & 25012 & 5990 & 23.94 & 76.06 & 14421 & 5554 & 38.51 & 61.49 \\
\hline
\end{tabular}

*Source: Computed from fieldwork, 2019 


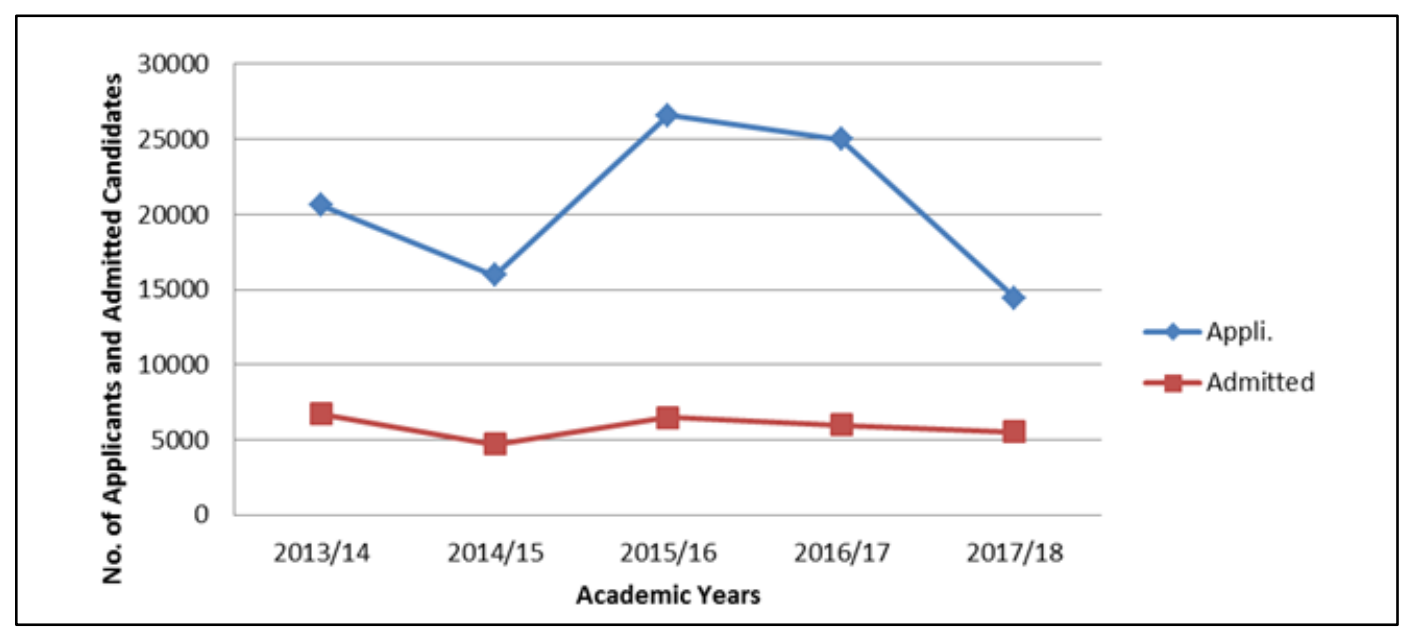

Figure 2. No. of Applicants and Admissions in DELSU from 2013/14 - 2017/18

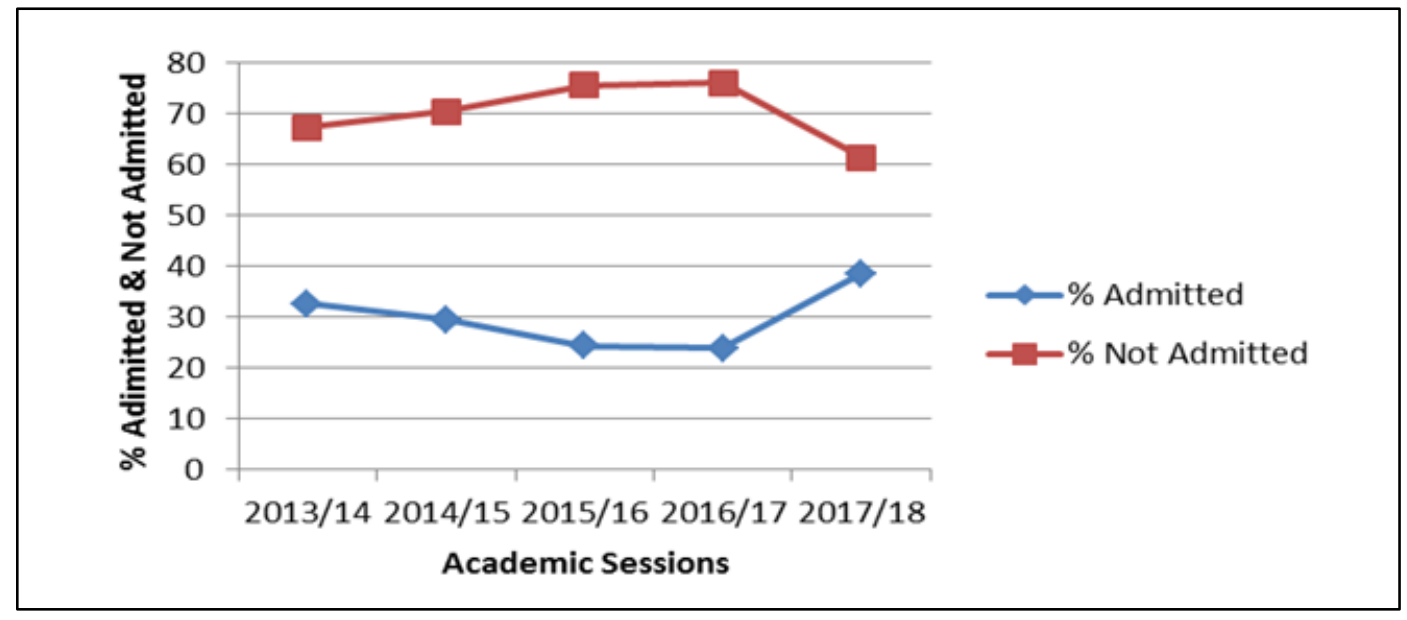

Figure 3. Overall Percentage Rate of Admitted to Not Admitted Candidates

\section{Research Question 1: What were the total numbers of applicants and admitted candidates across all disciplines in Delta State University for the 2013/14 - 2017/18 academic years?}

The data presented in Table 2 shows the total numbers of applicants and admitted candidates across all disciplines per year for 2013/14 - 2017/18 academic years. It shows that for 2013/14 academic session, 20605 candidates applied to DELSU while 6734 were offered admission. For 2014/15 session, while 15944 applied, 4702 were admitted. In the 2015/16 session, 26612 applied while 6480 were admitted. For 2016/17 session, 25012 applied while 5990 were admitted; and for the 2017/18 session, 14421 applied while 5541 candidates were admitted. Figure 2 shows the graphic representation of numbers of applicants and admitted candidates across all faculties for the five academic years studied.

Furthermore, the table shows the percentage admitted and percentage not admitted per faculty per session. The overall percentage rate of admitted and not admitted candidates for the period under review is graphically presented in Figure 3.
Research Question 2: What were the total numbers of applicants and admitted candidates per faculty per academic year in DELSU for the period under review?

Table 2 reveals the numbers of applicants and admitted candidates per faculty for the period under study. It points out the faculties with high numbers of applicants and admitted candidates. Faculties such as Social Sciences with applicants ranging from 3001 - 5841, Basic Medical Sciences (1703 - 3826), Science (1419 - 2947), Clinical Medicine (1346 - 3269), and Education (1145 - 2873) recorded high number of applicants while faculties such as Education with figures ranging from 1111 - 2038, Science (928 - 1711), Social Science (597 - 758) and Arts (557 -797) recorded high number of admissions comparatively for the academic years reviewed. Clinical Medicine and Pharmacy with admissions ranging from $58-78$ and $71-$ 106 respectively were faculties with the least number of admitted candidates for the years under review. Agriculture was the only faculty where admissions outweighed number of applicants. There were no admissions in the Faculty of Engineering until the 2016/17 and the 2017/18 sessions. These are graphically presented in Figure 4. 


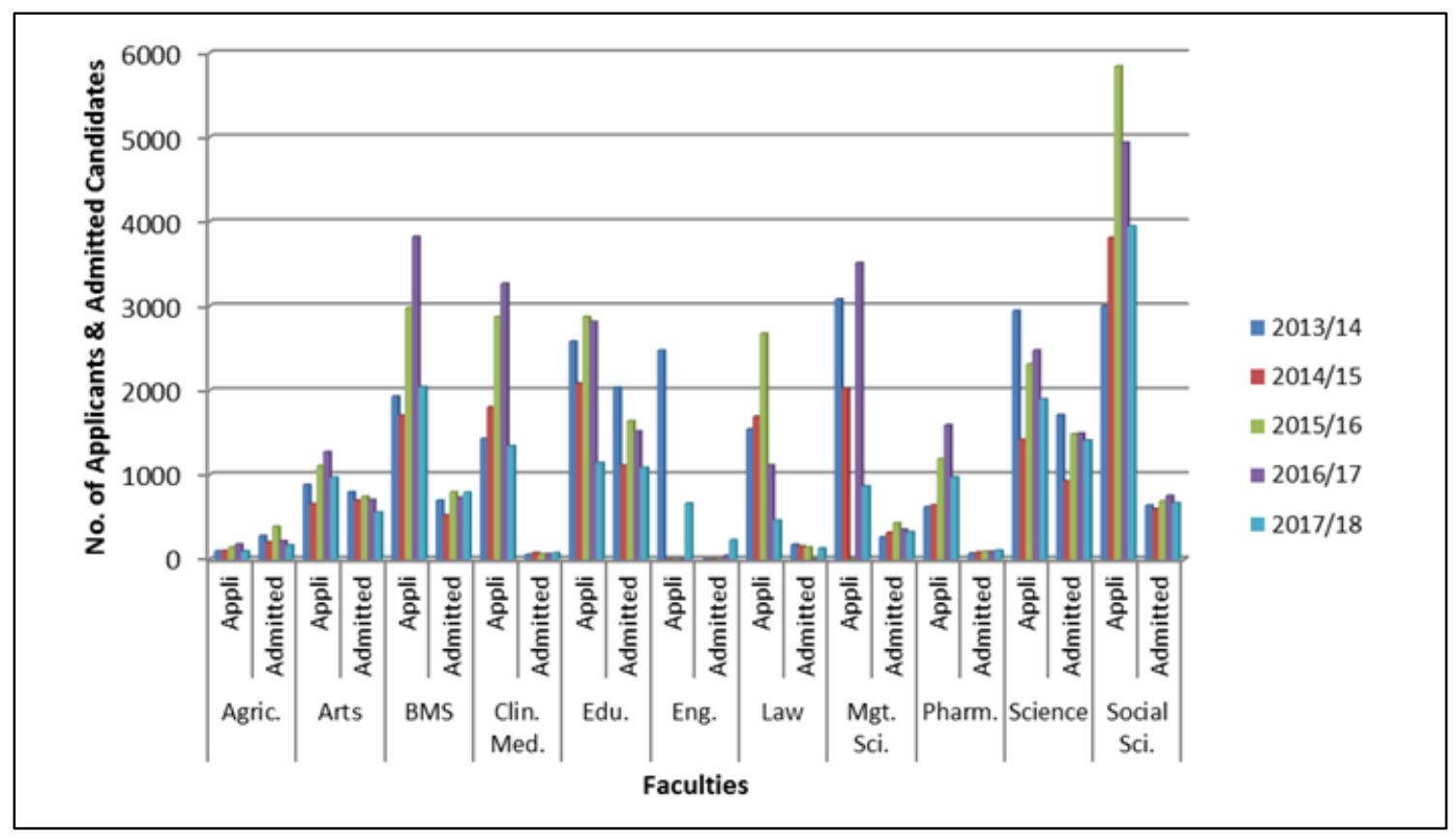

Figure 4. Number of Applicants and Admitted Candidates by Faculty

\section{Research Question 3: What was the percentage rate of admissions offered per academic year for the period 2013/14 - 2017/18?}

Table 2 also shows the percentage rate of admissions for the period studied. In absolute terms, it indicates the total percentage rate per academic year ranging from $23.94 \%-38.51 \%$ of the total number of applicants per session. But, in specific terms, faculties such as Agriculture (120.32 - 282.82), Arts (55.48 - 106.22), Education (53.28 - 95.1) and Science (58.05 - 74.11) recorded high percentage rate of admissions respectively. Clinical Medicine recorded the least range of $2.01-5.72 \%$ during the five years under review.

\section{Discussion}

This study exposed the applicants' and admissions situation in DELSU for $2013 / 14$ to $2017 / 18$ academic years. It revealed the total number of applicants and admitted candidates per session; with 2015/16 session having the highest number of 26612 applicants; while 2013/14 session had the highest number of 6734 admitted candidates. For the five academic years, the study revealed that 102,594 was the total number of applicants while 29,460 representing $28.72 \%$ was the total number of admitted candidates. The study affirms the analysis of $[13,14,15]$ where of the $11,270,384$ applicants between 2012 and 2018 , only $2,871,818$ representing $25.48 \%$ were offered admission for a period of seven years. Again, it supports Akpotu [23] assertions that the gap between the demand and supply of university education is widening over the years.
Furthermore, the study presents Social Sciences, Science, Education, Basic Medical Sciences, Clinical Medicine and Pharmacy as 'most sought after' faculties by applicants with Social Sciences recording the highest number of applicants $(5,843)$ for $2015 / 16$. It equally shows Education, Science, Social Sciences, Arts and Agriculture as faculties where candidates were mostly admitted with Education having the highest number of 2,038 for the $2013 / 14$ session. The study also shows Agriculture as the only faculty where admissions far outweighed the number of applicants throughout the years studied. This situation can be attributed to the numerous numbers of candidates entering the faculty through the pre-degree progamme. Also, the percentage of admissions into Agriculture over the years exceeded the applicants perhaps because many candidates do not want to study Agriculture and admissions are given candidates who originally did not opt for Agriculture.

The study equally indicates that there were no admissions for Faculties of Engineering for 2013/14 2015/16 and Law for 2016/17 academic years. This again may be the resultant effect of the accreditation status of both faculties during the period. Admissions into Clinical Medicine and Pharmacy were the 'worst hit' as both faculties recorded $5.72 \%$ and $11.37 \%$ of the number of applicants respectively as their highest rate of admission. This negates Otoja and Obodumu [18] who reported that between 2012 and 2015, disciplines such as Engineering/Environmental Technology, Medicine and Sciences have higher admissions for each year.

On the percentage rate of admitted candidates per academic year, the study indicated percentage rates ranging from $23.94 \%$ - $38.51 \%$ with $2017 / 18$ having the highest rate of $38.51 \%$ and $2016 / 17$ session recording the 
least of $23.94 \%$ during the period. The percentage rate of unmet admissions per session was between $61.49 \%$ $76.06 \%$. With an overall percentage rate of $28.72 \%$ of the total number of applicants admitted and $71.28 \%$ not admitted for the five years under review, the study corroborates Clark and Ausukuya [10] who reported that despite the steady growth in the number of universities approved to award degrees by the government, there is currently still more demand than there is supply of places.

\section{Implications for Educational Planning}

The findings of this study have once more exposed the high figures of unmet demand of university applicants as experienced in the country. This implies that a great gap still exists between the demand and supply of admission places in Delta State University. This ugly situation cannot be unconnected with the youth population explosion and the social demand approach to the planning of education at all levels including university education without recourse to the enormous educational resources (human, material and fiscal resources) that are needed for effective supply and delivery of university education. Therefore, education in Delta State University and by extension, Nigeria should be planned taking into consideration the availability and provision of the 'enormous educational resources' required for increasing the supply of admission places. It is only by so doing that a good number of the qualified applicants can be absorbed into the university.

\section{Conclusions}

The ever increasing demand for university education has remained unabated in the face of limited admission spaces. This study traced the trend of applicants and admissions in Delta State University for the 2013/14 2017/18 academic years and observed a wide worrisome gap between the numbers of applicants and admitted candidates during the period. The writer explored / investigated some factors affecting the demand and supply of university admission places to include low carrying capacity, inadequate educational facilities/infrastructures, insufficient funding, government admission policies, etc. For the university sector to be able to remain relevant in the training and development of human resources for national development, adequate human and material resources should be provided in the faculties of Basic Medical Sciences, Engineering and Pharmacy to be able to admit more applicants.

\section{Recommendations}

For the university to be able to admit more candidates, the following recommendations are proffered:
1. Stakeholders (government, management, philanthropists and Delta State University Alumni Association) should work towards the expansion of the university's facilities and infrastructures in order to increase the carrying capacity to enable the institution accommodate the ever increasing number of applicants. This expansion should equally be in the area of attracting adequate qualified manpower especially academics to man the programmes.

2. More of Tetfund intervention projects should be geared towards the expansion of infrastructures and facilities.

3. The re-introduction of Sandwich, Part-time programme and Continuous Education Programmes are sure strategies of giving more applicants the opportunities to be admitted.

4. It is also recommended that e-learning programmes should be introduced as this will give more candidates especially the physically challenged the opportunity to access university education.

5. The low admission figures recorded for Clinical Medicine, Engineering and Pharmacy calls for general concern as these are critical areas of need for the much needed scientific and technological development in Nigeria. Therefore, facilities in these areas should be expanded in order to absorb many more applicants.

\section{REFERENCES}

[1] Federal Republic of Nigeria. National Policy on Education, Abuja: NERDC Press, p. 28, 2014.

[2] Worldometer, 2020. www.worldometers.info.

[3] Western Education Service (WES). Education in Nigeria, 2017. https://wenr.wes.org/2017/03/education-in-nigeria. Retrieved on $13^{\text {th }}$ April, 2020.

[4] F. Bolaji. List of all Universities in Nigeria approved by NUC - 2020 Latest List. https://campusbiz.com.ng>list-ofuniversities. Retrieved on $17^{\text {th }}$ June, 2020.

[5] A. William. Microeconomics: A Contemporary Introduction. USA: South Eastern College Publishing, 2000.

[6] M. Nwadiani. Economic Dimension of Educational Planning in Nigeria: Theory and Practice. Benin-City: Monose Amalgamates, p. 18, 2000.

[7] O. G. Agabi. Finance and Economics of Public Education. Port Harcourt: International Centre for Educational Services, pp. $102-104,2002$.

[8] I. A. Ajayi, H. T. Ekundayo. 'The Deregulation of University Education in Nigeria: Implications for Quality Assurance'. Nebula Vol. 5 No. 4, pp 212 - 224, 2008.

[9] A. Adedigba. 'Only one percent of Nigerian Population in Universities - NUC' - Premium Times, 2018. 
https://www.premiumtimesng.com/news/top-news/274915only-... Retrieved on $17^{\text {th }}$ April, 2020.

[10] N. Clark, C. Asukuya, Education in Nigeria, WENR-WES, 2013.

https://wenre.wes.org/2013/07/an-overview-of-education-in -nigeria. Retrieved on $6^{\text {th }}$ July, 2016.

[11] S. A. Okecha. The Nigerian University: An Ivory Tower with Neither Ivory Nor Tower. Owerri: Edu-Edy Publications, pp. $11-12,2008$.

[12] JAMB Statistics 2010 - 2016 Applicants and Admission Statistics. https://www.jamb.gov.ng. Retrieved on $25^{\text {th }}$ April, 2020.

[13] I. O. Oloyede. 2017 Combined Policy Meeting on Admissions to Degree, NCE and ND Awarding Institutions. A JAMB Presentation held on Monday, $21^{\text {st }}$ and Tuesday, $22^{\text {nd }}$ August, 2017 at Andrew Otutu Obaseki Auditorium, National Judiciary Institute, Ring Road, Off Umar Musa Yar'adua (Airport) Road, Abuja.

[14] I. O. Oloyede. 2018 Policy Meeting on Admissions to Degree Awarding Institutions. A JAMB Presentation held on $26^{\text {th }}$ June, 2018 at Bola Babalakin Auditorium, Gbongan, Osun State.

[15] I. O. Oloyede. 2019 Policy Meeting on Admissions to Degree Awarding Institutions. A JAMB Presentation held on $11^{\text {th }}$ June, 2019 at JAMB National Headquarters, Bwari, Abuja.

[16] C. Parr. 2 Million applicants for $750 \mathrm{~K}$ places: Nigeria's bid to tackle its capacity issue, 2018. https://thepienews.com/an alysis/two-million-applicants-for-750k... Retrieved on $17^{\text {th }}$ April, 2020.

[17] K. Umana. Impact of Deregulation of University Education in Nigeria, 2018.https://researchcyber.com/impacts-deregul ation-university-education-nigeria/. Retrieved on $26^{\text {th }}$ April, 2020 .

[18] R. I. Otoja, E. Obodumu. Access to University Education in Nigeria: Issues and Trends, International Journal of Progressive and Alternative Education, Vol. 4 No. 1, pp 1 -
$11,2017$.

[19] N. E. Akpotu. Investment in Human Capital Development: Challenges and Pathways for Sustainable Funding in Nigeria'. Being the $61^{\text {st }}$ in the Series of Inaugural Lectures of Delta State University, Abraka, Nigeria held on Thursday, April 12, 2018, p. 50, 2018.

[20] O. Aluede, P. O. Idogho, J. Imonikhe. Increasing Access to University Education in Nigeria: Present Challenges and Suggestions for the Future, The African Symposium: An Online Journal of the African Education Research Network, Vol. 12 No. 1 pp 3 -13. 2012.

[21] M. G. Mahabub. The Challenges of Access to University Education in Nigeria. International Conference on Economics, Education and Humanities (ICEEH '14) 2014. http://dx.doi.org/10.15242/ICEHM.ED1214104. Retrieved on $17^{\text {th }}$ April, 2020.

[22] Approved Budget Analysis (2020). https://yourbudgit.com. Retrieved on $30^{\text {th }}$ April, 2020.

[23] N. E. Akpotu. Investing in Nigeria Education Beyond Budgetary Allocations: The Profitability and Constraints, 2013. In Arubayi, E. A., Akpotu, N. E. \& Oghuvbu, E. P. (Eds.) Investing in Education: Emerging Challenges. Abraka: Nigerian Association for Educational Administration and Planning (NAEAP), p. 60.

[24] O. I. Obielumani. Quota System and Educational Reforms in Nigeria, Journal of Research Development, Vol. 6 No. 1, pp 23-34 2008.

[25] N. S. Okoroma. Admission Policies and the Quality of University Education in Nigeria, Educational Research Quarterly, Vol. 31 No. 3, pp 1-24. 2008.

[26] A. Babalola. 'Why We Support the Post-JAMB Test'. The Guardian Newspaper. November 21, p. 15, 2005.

[27] T. Eluemunor. Post UME Test: Education Minister Versus Representatives. Sunday Independent Newspaper, November 13, pp. 13 - 16, 2005.

[28] C. Akani. Political Economy of Secret Cultism in Nigerian Universities. Port Harcourt: Christian Publishers, 1996. 